\title{
HEBERDEN'S NODES: THE MECHANISM OF INHERITANCE IN HYPERTROPHIC ARTHRITIS OF THE FINGERS ${ }^{1}$
}

\author{
By ROBERT M. STECHER AND A. H. HERSH \\ (From the Department of Medicine, City Hospital, and the Department of Biology, \\ Western Reserve University, Cleveland)
}

(Received for publication December 20, 1943)

In 2 previous papers, Heberden's nodes were described, the incidence of their occurrence in the general population was presented, and evidence was offered leading to the conclusion that this condition is hereditary. It is our purpose at the present time to offer additional data and to subject the material to modern methods of statistical and genetic analysis in order to discover the probable mechanism of inheritance of this form of joint disease.

Heberden's nodes are enlargements of the terminal interphalangeal joints of the fingers, due to hypertrophic arthritis (1). A survey of a cross-section of the general population showed that the condition sometimes occurs as a result of direct trauma to the fingers. Enquiry served to distinguish such nodes from another type arising spontaneously, the so-called idiopathic Heberden's nodes which are the subject of the subsequent discussion. The incidence of idiopathic Heberden's nodes was found to be higher in white people than in Negroes, it was higher in women than it was in men, and it increased markedly with age.

The second study (2) based upon 68 families demonstrated that the mothers of affected women showed the condition twice and the sisters 3 times as commonly as the women in the general population. In a control series, the sisters of unaffected women were involved as frequently as the population in general. Three combinations of familial involvement which were discovered in this series could not be expected to occur as a result of chance alone more frequently than once in $\mathbf{1 9 0}$ families for the first, once in $4,500,000$ for the second, and once in $10,000,000$ families for the third. An hereditary factor influencing the pro-

\footnotetext{
${ }^{1}$ Read by title at the sixteenth annual meeting of the Central Society for Clinical Research, Chicago, November $5,1943$.
}

duction of the condition in women seemed to be established.

The present study is based upon the pedigrees of 74 affected persons. The affected index cases and their siblings include 127 men and 215 women. The difference in the number of men and women in the group is due to the fact that 72 of the 74 index cases were women. When the index cases are subtracted from the total group, there remain 125 men and 143 women, a fair approximation to the proportions of men and women in the general population of this age distribution.

Examination of the pedigrees shows at once that the incidence in women is high compared to that in men. For this reason, each sex will be considered separately in the genetic analysis. Considering first the women, it is found that 108 of the 215 women, or one-half, are affected, the 1:1 ratio suggesting immediately that the character depends upon a single autosomal dominant gene. When this is the case, one parent is invariably expected to be affected. Actually, mothers are recorded affected in 25 of the 74 families. In 2 families, the maternal grandmother was involved but the mothers, dying before the ages of 35 years, were spared. Only 1 father was recorded affected. This family added nothing to the genetic analysis because the mother was also affected and only 1 daughter, the index case, resulted from the match. In 4 families without the mother affected, there is reason to believe that the character was transmitted through the unaffected father. In 2 instances, the paternal grandmother and in 2 other instances, a paternal aunt had Heberden's nodes. In 11 families, including the 2 mentioned above, the mothers died before the age of 50 so might have been genetically affected without demonstrating the character. In 4 families, women were affected in $\mathbf{3}$ successive generations. Of the 
74 families, some antecedent involvement was discovered in 42 instances but it was lacking in 32 others.

Although Heberden's nodes may seem to be dominant in women, they certainly are not so in men. Of the 127 males of this series, only 4 are recorded affected. They may be recessive. Genetic examples are recognized of factors dominant in one sex and recessive in the other. These include color variations in cattle, the development of horns in sheep, and hereditary baldness in humans. Baldness is dominant in men and recessive in women (3). With the heterozygous constitution (Aa), men develop the trait and transmit it to one-half of their offspring. Women with this constitution do not - exhibit the condition but transmit it to one-half of their children. Women become bald only when they are homozygous (AA). With Heberden's nodes, the simplest modification is to assume that the condition is recessive in men. With matings of the Aa $\mathrm{x}$ aa type, one-half of all children will be heterozygous (Aa). The women of this constitution will develop the condition while the men will not. The men who are affected would be homozygous (AA). According to this assumption, an equal number of men and of women are of the heterozygous (Aa) constitution and such men may have been the fathers in those families where no antecedent involvement was known. Furthermore, for a man to be affected, both parents must transmit the character to him but only the mother is likely to show it.

The above hypothesis was tested by gene frequency analysis. For the subsequent discussion, $D$ will be used to represent the dominant gene for Heberden's nodes and $d$ the recessive normal allele. In the former study, the highest incidence in white women over 70 years was found to be about 30 per cent. If this is accepted as complete penetrance, we may assume that $\mathbf{7 0}$ per cent of women are homozygous recessives and are $d d$ in constitution, or completely normal so far as Heberden's nodes are concerned. The proportion of the 30 per cent who are $D d$ and $d d$ in constitution may be readily calculated from the well-known formula for gene frequency analysis in a population in genetic equilibrium mating at random. According to the formula, homozygous dominants $D D$, heterozygous $D d$, and homozygous recessives $d d$ are present in the population in the relative numbers $q^{2}, 2 p q$, and $p^{2}$, respectively, where $p$ plus $q$ equals 1 . Since $p^{2}$ is 0.70 , the value of $p$ is 0.837 from which $q$ is readily known from the relation p plus q equals 1 . The values of $2 p q$ and $q^{2}$ are easily calculated. The result shows that individuals with the constitutions $D D, D d$, and $d d$ are present in the population with the relative proportions of 0.027 , 0.272 , and 0.70 , respectively. According to this hypothesis, males of the constitution $D d$ are phenotypically normal so that only 2.7 per cent of males have a genetic constitution which would cause the trait to develop.

In the original survey of the population in general, a rapid rise in incidence in females was found from 2.6 per cent at the sixth decade to an approach to an upper asymptote of nearly 30 per cent in the ninth decade. In males, the incidence rose from 3.6 per cent in the sixth decade to 8.4 per cent in the eighth decade with no approach to an asymptote. In a small sample in the ninth decade, an incidence of 18.2 per cent was found. Because the incidence varied so markedly from one sex to the other and the incidence found in the original survey was so different from the theoretical expected from the gene frequency analysis, a second survey was undertaken, confined to white men and women 70 years or more of age. Every patient of this description admitted to City Hospital was examined, as well as the inmates of 4 homes for the aged. In the course of 3 months, 151 men and 184 women were observed and the results tabulated in Table I. The incidence in women was very close to the original estimate, substantiating the previous observations and strengthening the

TABLE I

The incidence of Heberden's nodes-Second series White men and women, 70 years of age or older

\begin{tabular}{c|c|c|c|c|c|c}
\hline \hline & \multicolumn{3}{|c|}{ Men } & \multicolumn{3}{c}{ Women } \\
\cline { 2 - 7 } Age & $\begin{array}{c}\text { Subjects } \\
\text { exam- } \\
\text { ined }\end{array}$ & $\begin{array}{c}\text { Number } \\
\text { affected }\end{array}$ & $\begin{array}{c}\text { Percent- } \\
\text { age } \\
\text { affected }\end{array}$ & $\begin{array}{c}\text { Subjects } \\
\text { exam- } \\
\text { ined }\end{array}$ & $\begin{array}{c}\text { Number } \\
\text { affected }\end{array}$ & $\begin{array}{c}\text { Percent- } \\
\text { age } \\
\text { affected }\end{array}$ \\
\hline $70 ' s$ & 124 & 4 & 3.2 & 117 & 28 & 23.9 \\
$80 ' s$ & 24 & 1 & 4.2 & 58 & 21 & 36.2 \\
$90 ' s$ & 3 & 0 & 9 & 3 & 33.3 \\
\hline Total & 151 & 5 & 3.3 & 184 & 52 & 28.3 \\
\hline
\end{tabular}


contention of an ultimate incidence of 30 per cent after complete penetrance. The observation of men was at marked variance from the original findings, only about 3 per cent affected being found instead of 8 to 18 per cent. Increased experience with the condition over a period of 6 years served to eliminate more accurately the cases of traumatic nodes which had previously been included.

Since the proportions of the various constitutions for Heberden's nodes are known, the types of matings which can be expected to occur at random can be predicted. They are given in Table II. The top figure gives the proportion of each type of mating expected and the second figure gives the actual number of each type of mating expected in this group of 74 families. Since each pedigree was discovered through an affected child and never from a parent, no mating of type dd $\mathrm{x}$ dd is included. The frequencies of

TABLE II

Types of mating for Heberden's nodes

First number in each cell is the proportion in the population. Second figure is actual number expected in this series of $\mathbf{7 4}$ families.

\begin{tabular}{|c|c|c|c|c|}
\hline & \multicolumn{4}{|c|}{ Constitution of the mothers } \\
\hline & & $\begin{array}{c}D D \\
q^{2}=0.027\end{array}$ & $\begin{array}{c}\mathrm{Dd} \\
2 \mathrm{pq}=0.272\end{array}$ & $\begin{array}{c}\mathrm{dd} \\
\mathrm{p}^{2}=0.70\end{array}$ \\
\hline \multirow{3}{*}{$\begin{array}{l}\text { Consti- } \\
\text { tion } \\
\text { of the } \\
\text { fathers }\end{array}$} & $\begin{array}{c}\text { DD } \\
\mathrm{q}^{2}=0.027\end{array}$ & $\begin{array}{l}0.00073 \\
0.1\end{array}$ & $\begin{array}{l}0.0073 \\
1.1\end{array}$ & $\begin{array}{l}0.0189 \\
2.8\end{array}$ \\
\hline & $\begin{array}{c}\mathrm{Dd} \\
2 \mathrm{pq}=0.272\end{array}$ & $\begin{array}{l}0.0073 \\
1.1\end{array}$ & $\begin{array}{l}0.074 \\
10.8\end{array}$ & $\begin{array}{l}0.1904 \\
28 .\end{array}$ \\
\hline & $\begin{array}{c}\mathrm{dd} \\
\mathrm{p}^{2}=0.70\end{array}$ & $\begin{array}{l}0.0189 \\
2.8\end{array}$ & $\begin{array}{l}0.1904 \\
28 .\end{array}$ & $\begin{array}{l}0.490 \\
\text { None }\end{array}$ \\
\hline
\end{tabular}

the 8 different types of pedigrees with the genetic constitutions of the parents are shown in Table III. The matings are sorted into 4 groups depending on whether both parents, the mother alone, the father alone, or neither parent has the constitution for the development of Heberden's nodes according to the hypothesis being tested.

Although it is not possible to recognize the different genotypes with certainty in all families, an attempt at rough classification is justified. According to Table III, 44 families with inheritance from the mother are expected. Of these, 29 are identified with a fair degree of certainty. These include 25 families with mother affected,
TABLE III

Frequency of matings of phenotypes among 74 families with expected proportion of affected children Dominant in women, recessive in men

\begin{tabular}{|c|c|c|c|c|c|}
\hline \multirow{2}{*}{$\begin{array}{c}\text { Phenotype } \\
\text { of } \\
\text { parents }\end{array}$} & \multicolumn{2}{|c|}{$\begin{array}{l}\text { Genotype of } \\
\text { parents }\end{array}$} & \multirow{2}{*}{$\begin{array}{c}\text { No. of } \\
\text { families } \\
\text { of this } \\
\text { series }\end{array}$} & \multicolumn{2}{|c|}{$\begin{array}{c}\text { Proportion of children } \\
\text { affected }\end{array}$} \\
\hline & Mother & Father & & Sons & Daughters \\
\hline $\begin{array}{c}\text { Both } \\
\text { parents } \\
\text { affected }\end{array}$ & $\begin{array}{l}\text { DD } \\
\text { Dd }\end{array}$ & $\begin{array}{l}\text { DD } \\
\text { DD }\end{array}$ & $\begin{array}{l}0.1 \\
1.1\end{array}$ & $\underset{\text { One-half }}{\text { All }}$ & $\begin{array}{l}\text { All } \\
\text { All }\end{array}$ \\
\hline $\begin{array}{l}\text { Mother } \\
\text { only } \\
\text { affected }\end{array}$ & $\begin{array}{l}\text { DD } \\
\text { DD } \\
\text { Dd } \\
\text { Dd }\end{array}$ & $\begin{array}{l}\text { Dd } \\
\text { dd } \\
\text { Dd } \\
\text { dd }\end{array}$ & $\begin{array}{r}1.1 \\
2.8 \\
10.8 \\
28.0\end{array}$ & $\begin{array}{c}\text { One-half } \\
\text { None } \\
\text { One-fourth } \\
\text { None }\end{array}$ & $\begin{array}{c}\text { All } \\
\text { All } \\
\text { Three-fourths } \\
\text { One-half }\end{array}$ \\
\hline $\begin{array}{l}\text { Father } \\
\text { only } \\
\text { affected }\end{array}$ & dd & DD & 2.8 & None & All \\
\hline $\begin{array}{l}\text { Neither } \\
\text { parent } \\
\text { affected }\end{array}$ & dd & Dd & 28.0 & None & One-half \\
\hline
\end{tabular}

2 families with maternal grandmother affected, and 2 additional families with affected sons. Assuming random mating, 12 heterozygous fathers are expected in this group of 44 families, leading to double inheritance and a 3:1 ratio of expected affected. Of the 29 families identified, therefore, we expect an appreciably greater frequency than the straight $1: 1$ ratio.

According to the table of matings, 28 families are expected with no parent showing the trait. Actually, 35 families were found without suspected inheritance from the mother. It is concluded that inheritance is through the father and the ratio of $1: 1$ affected is expected. Ten additional families have been omitted from the above classifications because the mother died so young that her constitution could not be recognized.

The above ratios are theoretical and cannot be realized in material such as is dealt with here. Corrections can be made for small family size and for lack of penetrance. The desirability of the first is obvious. Those families, of proper matings to transmit the character, which have only normal children, must be counted to attain expected proportions of affected and unaffected children. The corrections are made according to the method of Hogben (4).

In Table IV are 29 families with known maternal inheritance. Of 95 daughters, 53 are observed affected compared to $54.5 \pm 4.16 \mathrm{ex}$ - 
TABLE IV

Comparison of affected daughters with theoretical expectation on basis of simple autosomal dominant (1:1 ratio)

Corrected for family size, in families with mother or maternal ancestor known to be affected

\begin{tabular}{c|c|c|c|c|r|c}
\hline \hline $\begin{array}{c}\text { No. of } \\
\text { daugh- } \\
\text { ters }\end{array}$ & $\begin{array}{c}\text { No. of } \\
\text { fami- } \\
\text { lies }\end{array}$ & $\begin{array}{c}\text { Total } \\
\text { daugh- } \\
\text { ters }\end{array}$ & $\begin{array}{c}\text { Ob- } \\
\text { served } \\
\text { affected }\end{array}$ & $\begin{array}{c}\text { Correc- } \\
\text { tive } \\
\text { factor }\end{array}$ & $\begin{array}{c}\text { Ex- } \\
\text { pected } \\
1: 1 \text { ratio }\end{array}$ & $\sigma^{2 *}$ \\
\hline 1 & 5 & 5 & 5 & 1.0 & 5.000 & 0.000 \\
2 & 8 & 16 & 10 & 1.333 & 10.664 & 1.778 \\
3 & 3 & 9 & 5 & 1.714 & 5.142 & 1.469 \\
4 & 5 & 20 & 10 & 2.133 & 10.665 & 3.911 \\
5 & 5 & 25 & 8 & 2.581 & 12.905 & 5.410 \\
6 & 2 & 12 & 8 & 3.048 & 6.096 & 2.758 \\
8 & 1 & 8 & 7 & 4.016 & 4.016 & 1.945 \\
\hline Totals & 29 & 95 & 53 & & 54.488 & 17.271 \\
& & & & & & $\sigma \pm 4.16$ \\
\hline
\end{tabular}

* The term $\sigma^{2}$, also called variance, is the square of the standard deviation. Differences between observed and expected results greater than 3 times the standard deviation cannot be expected to occur by chance alone more of ten than about 3 times in 1000 . The figures for variance in Tables IV and V are taken from Hogben.

pected affected. In Table $\mathrm{V}$ are 35 families without maternal inheritance. Of 96 daughters, 46 were found affected compared to $57.6 \pm 3.9$ expected. The difference is 11.6 or 3 times the standard deviation. It is seen that a higher proportion of affected is found in the group with suspected double inheritance than in that with single inheritance.

Further correction must be made for lack of penetrance, and is attempted as follows. The onset of the condition is insidious and an exact date of first appearance is rarely remembered by the patient. However, in 95 instances in women, an approximate age of onset seemed reasonably reliable. The age of onset ranged from 30 to 65 years. The mean age of onset was
48.5 years; the median age was 49.2 years. Three-fourths of these women were affected by the age of 54.3 years. Applying this information, Table VI was devised. It will be seen that in the first group, 66.3 are finally expected affected compared to 53 actually found. In the second group, 53.6 are finally expected affected compared to 46 actually found. In the first group, after correction for incomplete penetrance, 70 per cent of the daughters are finally expected affected compared to 56 per cent in the second group. Correction for incomplete penetrance can be computed in another manner leading to essentially the same results. In the group with known affected maternal ancestors, there are 46 women above the age of 55 years when penetrance may be considered complete. Of these, 33 , or 72 per cent, are affected. If this proportion of affected is applied to the entire group, the result is 68.4 as compared to 66.3 previously found. In the group without inheritance from the mother, 63 women are 55 years or older and of these, 35 or 56 per cent are affected. Fifty-six per cent of 96 is $\mathbf{5 3 . 7}$ compared to $\mathbf{5 3 . 6}$ previously obtained. Thus it is seen that corrections for incomplete penetrance, made in two different manners, produce the same result.

After the above corrections, it is seen that in 29 families with known maternal inheritance, and suspected paternal inheritance in about one-third of them, 70 per cent of the daughters are finally expected affected. In 35 families without suspected maternal inheritance and with paternal inheritance only, 53.6 per cent of the daughters are finally expected affected. The latter is very close to the theoretical $1: 1$ ratio while the other

TABLE V

Comparison of affected daughters with theoretical expectancy on basis of simple dominant (1:1 ratio), and since neither parent shows the trait, also on basis of $3: 1$ ratio

Corrected for family size

\begin{tabular}{|c|c|c|c|c|c|c|c|c|c|}
\hline \multirow{2}{*}{$\begin{array}{l}\text { No. of } \\
\text { daughters }\end{array}$} & \multirow{2}{*}{$\begin{array}{c}\text { No. of } \\
\text { families }\end{array}$} & \multirow{2}{*}{$\begin{array}{c}\text { Total } \\
\text { daughters }\end{array}$} & \multirow{2}{*}{$\begin{array}{l}\text { Affected } \\
\text { daughters }\end{array}$} & \multicolumn{3}{|c|}{ 1:1 ratio } & \multicolumn{3}{|c|}{$3: 1$ ratio } \\
\hline & & & & Factor & Expected & $\sigma^{2}$ & Factor & Expected & $\sigma^{2}$ \\
\hline \multirow[t]{2}{*}{$\begin{array}{l}1 \\
2 \\
3 \\
4 \\
5\end{array}$} & $\begin{array}{r}10 \\
3 \\
11 \\
8 \\
3\end{array}$ & $\begin{array}{r}10 \\
6 \\
33 \\
32 \\
15\end{array}$ & $\begin{array}{r}10 \\
3 \\
13 \\
14 \\
6\end{array}$ & $\begin{array}{l}1.000 \\
1.333 \\
1.714 \\
2.133 \\
2.581\end{array}$ & $\begin{array}{r}10 . \\
4.000 \\
18.854 \\
17.064 \\
7.743\end{array}$ & $\begin{array}{l}0.000 \\
0.666 \\
5.388 \\
6.157 \\
3.246\end{array}$ & $\begin{array}{l}1 . \\
1.143 \\
1.297 \\
1.463 \\
1.672\end{array}$ & $\begin{array}{r}10 . \\
3.429 \\
14.067 \\
11.704 \\
5.017\end{array}$ & $\begin{array}{l}0.367 \\
2.893 \\
3.360 \\
1.776\end{array}$ \\
\hline & 35 & 96 & 46 & & 57.661 & $\begin{array}{c}15.457 \\
\sigma= \pm 3.9\end{array}$ & & 44.217 & $\begin{array}{c}8.396 \\
\sigma= \pm 2.9\end{array}$ \\
\hline
\end{tabular}


TABLE VI

Correction for incomplete penetrance

\begin{tabular}{|c|c|c|c|c|c|c|c|}
\hline \multirow{2}{*}{$\begin{array}{c}\text { Age group, } \\
\text { years }\end{array}$} & \multirow{2}{*}{$\begin{array}{c}\text { Degree of } \\
\text { penetrance }\end{array}$} & \multicolumn{3}{|c|}{29 families with known affected maternal ancestor } & \multicolumn{3}{|c|}{35 families without known affected maternal ancestor } \\
\hline & & $\begin{array}{c}\text { Total } \\
\text { daughters }\end{array}$ & $\begin{array}{l}\text { Affected } \\
\text { daughters }\end{array}$ & $\begin{array}{c}\text { Finally expected } \\
\text { affected }\end{array}$ & $\begin{array}{c}\text { Total } \\
\text { daughters }\end{array}$ & $\begin{array}{c}\text { Affected } \\
\text { daughters }\end{array}$ & $\begin{array}{c}\text { Finally expected } \\
\text { affected }\end{array}$ \\
\hline \multirow[t]{2}{*}{$\begin{array}{l}30 \text { to } 48 \\
49 \text { to } 54 \\
55+\end{array}$} & $\begin{array}{l}\text { One-half } \\
\text { Three-quarters } \\
\text { Complete }\end{array}$ & $\begin{array}{l}24 \\
25 \\
46\end{array}$ & $\begin{array}{l}10 \\
10 \\
33\end{array}$ & $\begin{array}{l}20 \\
13.3 \\
33\end{array}$ & $\begin{array}{r}24 \\
9 \\
63\end{array}$ & $\begin{array}{r}6 \\
5 \\
35\end{array}$ & $\begin{array}{l}12 \\
6.6\end{array}$ \\
\hline & & 95 & 53 & $\begin{array}{c}66.3 \\
70 \text { per cent }\end{array}$ & 96 & 46 & $\begin{array}{c}53.6 \\
56 \text { per cent }\end{array}$ \\
\hline
\end{tabular}

is over $2: 1$. In 4 families with known double inheritance and with affected sons, we expect a $3: 1$ ratio of affected daughters. Of 11 daughters in these families, 8 were known to have been affected. Even without correction this is very close to the theoretical expectancy of $3: 1$.

The second group of pedigrees mentioned above may be used for a further test of the hypothesis that the trait is dominant in females but recessive in males. In this group of 35 pedigrees, neither parent shows the trait although some of the children do and so conform to the rule of thumb for the identification of a simple autosomal recessive characteristic. By the hypothesis under scrutiny, these matings are of type $8 \mathrm{dd} \times \mathrm{Dd}$ and so the father, although phenotypically normal, is heterozygous in genetic constitution. The ratio of expected affected among the daughters is $1: 1$ in contrast to $3: 1$ if the trait is recessive. The numerical test of these opposed assumptions is made in Table V. It may be seen that, after correction for incomplete penetrance, 53 are finally expected affected. On the basis of dominance, $57.7 \pm 3.9$ and on the basis of a recessive, $44.2 \pm 2.8$ are expected. These data more nearly conform to and support the theory that the trait is dominant rather than recessive.

The hypothesis that Heberden's nodes are recessive was further tested. For this purpose, let $N$ denote the normal dominant gene and $n$ its recessive allele. The approximately 30 per cent of women who show the trait when penetrance is complete are $n n$ in constitution. Applying the equation for gene frequency analysis, the relative numbers in the population of homozygous normals, $N N$, heterozygotes, $N n$, and homozygous recessives, $n n$, are $0.204,0.495$, and 0.30 , re- spectively. Assuming random mating, the frequencies of those types of matings capable of having children susceptible to Heberden's nodes among the 74 pedigrees are given in Table VII. It will be noted that 28 pedigrees are expected with the father affected compared to 4 expected under the other theory and one actually found. Moreover, 10 pedigrees are expected with both parents and all the offspring affected. Actually but one was found. We expect to find 17 families with the mother affected but 29 are found. We expect only 29 families with no parent affected but 35 are found. On the hypothesis of a recessive, the sex difference must be regarded as arbitrary. The observed data lend no support to the theory that Heberden's nodes are recessive.

\section{CONCLUSIONS}

Heberden's nodes show certain peculiarities from the genetic standpoint. These include (1) a great preponderance among women, about 30 per cent compared to 3 per cent in men, or a ratio of $10: 1$ in the general population; (2) multiple involvement among female sibships without broth-

\section{TABLE VII}

Frequency of matings of phenotypes among 74 families with expected proportions of affected children Simple recessive

\begin{tabular}{|c|c|c|c|c|c|}
\hline \multirow{2}{*}{$\begin{array}{l}\text { Phenotype of } \\
\text { parents }\end{array}$} & \multicolumn{2}{|c|}{$\begin{array}{l}\text { Genotype of } \\
\text { parents }\end{array}$} & \multirow{2}{*}{$\begin{array}{l}\text { No. of } \\
\text { families } \\
\text { of this } \\
\text { series }\end{array}$} & \multicolumn{2}{|c|}{$\begin{array}{l}\text { Proportion of } \\
\text { children affected }\end{array}$} \\
\hline & Mother & Father & & Sons & Daughters \\
\hline $\begin{array}{l}\text { Both parents } \\
\text { affected } \\
\text { Mother only } \\
\text { affected } \\
\text { Father only } \\
\text { affected } \\
\text { Neither parent } \\
\text { affected }\end{array}$ & $\begin{array}{l}\text { nn } \\
\text { nn } \\
\mathrm{Nn} \\
\mathrm{Nn}\end{array}$ & $\begin{array}{l}\text { nn } \\
\mathbf{N n} \\
\mathbf{n n} \\
\mathbf{N n}\end{array}$ & $\begin{array}{l}10.5 \\
17.4 \\
17.4 \\
28.7\end{array}$ & $\begin{array}{l}\text { All } \\
\text { One-half } \\
\text { One-half } \\
\text { One-fourth }\end{array}$ & $\begin{array}{l}\text { All } \\
\text { One-half } \\
\text { One-half } \\
\text { One-fourth }\end{array}$ \\
\hline
\end{tabular}


ers being affected; (3) transmission through females in a manner to suggest maternal unilateral inheritance; (4) a greater frequency in families with mothers involved; (5) fathers rarely affected; (6) approximation to $1: 1$ ratio among the daughters in families where neither parent is affected; (7) a high incidence in sisters of affected men. In spite of the apparent lack of agreement with mendelian ratios, the analysis shows, on the basis of numerical tests, that the data support the hypothesis that the genetic mechanism involves a single autosomal gene, sex influenced, dominant in females and recessive in males.

This hypothesis accounts satisfactorily for all the genetic peculiarities of Heberden's nodes as exhibited by the 74 pedigrees. The unusual feature of the simple mechanism postulated is the effect of sex on dominance. Dominance is a phenotypic property which has long been recognized to be readily modified by the genetic back- ground and also by environmental factors. It is consistent with current opinion of physiological genetics to suppose that the effective or threshold concentration of some substance necessary for a reaction to occur, or of a substance which prevents a reaction from occurring, can be altered in such a way as to allow for an autosomal gene to be dominant in one sex and recessive in the other.

\section{BIBLIOGRAPHY}

1. Stecher, R. M., Heberden's nodes: The incidence of hypertrophic arthritis of the fingers. New England J. Med., 1940, 222, 300.

2. Stecher, R. M., Heberden's nodes. Heredity in hypertrophic arthritis of the finger joints. Am. J. M. Sc., 1941, 201, 801.

3. Osborn, D., Inheritance of baldness. J. Heredity, 1916, 7, 347.

4. Hogben, L., Nature and Nurture. Norton and Co., New York, 1933. 